RADOVI

Zavoda za znanstveni rad HAZU Varaždin

SINIŠA HORVAT

Prva gimnazija, Varaždin sinisa.horvat@vz.t-com.hr
UDK 371.83:94(497.523Varaždin)“1914/1918“

Izvorni znanstveni članak

Original Scientific Paper

Primljeno: 27. 02. 2017.

Prihvaćeno: 27. 06. 2017.

DOI: http://doi.org/10.21857/ygjwrc6e5y

\title{
DJELOVANJE VARAŽDINSKIH GIMNAZIJSKIH SKAUTA POČETKOM PRVOG SVJETSKOG RATA
}

\author{
Autor u radu daje pregled aktionosti varaždinskih srednjoškolaca \\ skauta početkom Proog svjetskog rata.
}

\section{NASTANAK SKAUTSKOG POKRETA}

Ideja o osnivanju skautskog pokreta, na našim prostorima često nazivanog izviđački pokret, proizašla je iz praktičnog životnog iskustva njegovog utemeljitelja, britanskog časnika Roberta Baden Powella (1857.-1941.). Po završetku svojeg školovanja on se kao mladi časnik pridružio britanskim postrojbama u Burskom ratu (1899.- 1902.), karakterističnom po bespoštednom gerilskom načinu ratovanja, dugim opsadama i dugim boravcima $u$ divljini te bez redovitog snabdijevanja i veza s glavninom svojih vojnih snaga. Budući da je, boraveći na terenu, stekao bogato iskustvo i savladao brojne vještine potrebne za preživljavanje u prirodi, nakon povratka u domovinu, on je kao neosporni autoritet, stečena znanja i vještine nastojao prenijeti na mlađe naraštaje i primijeniti ih u okviru građanskog društva. Pritom je želio pridonijeti odgajanju zapuštene gradske djece i mladeži izvan školskih prostora, radom i životom u prirodi u kojem svi sudjeluju, međusobno surađuju i pružaju podršku jedni drugima. Svladavanjem pojedinih vještina i znanja koje se prenose kroz igru i zabavu nastojao je utjecati na oblikovanje njihove osobnosti. U okviru svojih nastojanja, 1. kolovoza 1907. godine, organizirao je pokusni kamp za dvadeset dvojicu dječaka porijeklom iz različitih društvenih slojeva. Kamp je održan na britanskom otočiću Brownsea i vođen je prema skautskim zakonima i sustavu patrole. Stoga se upravo 1907. godina smatra godinom utemeljenja skautskog pokreta.

Potaknut pozitivnim iskustvima i oduševljenjem sudionika spomenutog kampa, Robert Baden Powell je napisao, i 1908. godine u šest nastavaka objavio, djelo Scouting 
for Boys (Izviđaštvo za dječake) koje je preraslo u skautski priručnik i s vremenom je prevedeno na više od trideset i pet jezika. Želeći si olakšati snalaženje u prirodi i u svakodnevnom životu, skauti su, upoznajući divljinu i boraveći u njoj, morali naučiti kako planirati odlazak u prirodu, podizati šator, oblikovati zaklon, naložiti vatru, pripremiti hranu, ukratko preživjeti u prirodi. Osim tih osnovnih znanja skauti su svladavali i vještine signaliziranja, čitanja i izrade zemljovida, snalaženja u prostoru, učili su o higijeni, pružanju prve pomoći i slično. Razvijali su prijateljstvo i spremnost na međusobno pomaganje i suradnju. Svaki je skaut morao biti odgovoran prema sebi i drugima, štedljiv, pažljiv, odan, častan i hrabar.

Ideje o takvom odgoju mladih ubrzo su se proširile u drugim državama pa se skautski pokret izuzetno brzo proširio cijelim svijetom i brojne skupine dječaka željele su se pridružiti pokretu. Godine 1910. Robert Baden Powell je potaknuo i osnivanje ženske skautske organizacije te se u potpunosti posvetio organiziranju pokreta. U svemu je imao podršku svoje 30-ak godina mlađe supruge Olave koja je ubrzo preuzela vođenje svjetske skautske organizacije za djevojke.

Na hrvatskim područjima koja su tada bila u sastavu Austro-ugarske Monarhije, još od 1881. godine, po srednjim školama su se počele osnivati učeničke izletne družbe. Sve je započelo u vinkovačkoj srednjoj školi gdje je spomenute godine predavač prirodoslovne skupine predmeta i gimnastike, Mate Mudrinić (1855.1932.), inače iskreni ljubitelj prirode i izniman pedagog, osnovao prvu učeničku izletnu družbu po uzoru na slične udruge u ostalim austro-ugarskim zemljama, koje su se bavile predvojničkom obukom za djecu školske dobi. Budući da se zalagao za izvođenje nastavnog procesa u prirodi u neposrednom doticaju s proučavanim pojavama, gdje bi učenici, osim teorijskog znanja, mogli stjecati i brojna praktična iskustva korisna za život, svojom nastavnom praksom se znatno približio načelima koja će više od 20-ak godina kasnije promovirati Robert Baden Powell, pa se to smatra začetkom domaćeg skautskog pokreta. ${ }^{1}$

Spomenute učeničke izletne družbe su se osnivale po cijeloj Hrvatskoj te su od 1913. godine nazivane skautima, prihvaćajući načela i principe osnivača. Sljedeće godine Mate Mudrinić je objavio Rukovođ za đačke izletne družbe (scout-družbe) - prema scoutskom sustavu koji sadrži osnove rada ovih družbi te je sudjelovao u osnivanju Uprave hrvatskih skautskih udruženja. Hrvatsko skautsko udruženje bilo je utemeljeno u Zagrebu 1914. godine, neposredno pred izbijanje Prvog svjetskog rata.

Herci GANZA ČALJKUŠI: Hrvatska - preteča skautizma, Povijest hrvatskog sporta br. 155, 2010., str. $7-10$. 


\section{SKAUTSKA UDRUGA NA VARAŽDINSKOJ GIMNAZIJI}

Neposredno pred izbijanje Prvog svjetskog rata u profesorskom zboru varaždinske Gimnazije započela je smjena generacija. Profesorski zbor bio je pomlađen prilivom novog predavačkog kadra koji je na području odgoja i obrazovanja počeo oblikovati nove metode i pristupe u nastavi i originalne načine rada s učenicima. Iz njihovih redova potekla je inicijativa za organiziranje stručno vođenih izleta i učeničkih ekskurzija u okviru kojih bi se znanja učenicima prenosilo izvan učionica. Učenici su znanja stjecali na terenu u neposrednom dodiru s izučavanim pojavama, što je bilo u skladu s nastojanjima Mate Mudrinića, utemeljitelja skautizma na ovim prostorima. Jedan od nositelja ovakvih aktivnosti na varaždinskoj Gimnaziji bio je profesor Franjo Košćec (1882.- 1968.), također predavač prirodoslovne skupine predmeta. ${ }^{2} \mathrm{U}$ svojoj nastavnoj praksi on je počeo organizirati odlazak učenika u okolicu Varaždina gdje su se konkretna znanja usvajala promatranjem pojava u njihovom prirodnom okruženju. Premda ovdje nije bila formalno utemeljena učenička izletna družina, već tijekom školske godine 1910./11. profesor Košćec je u nekoliko navrata poveo učenike u bližu okolicu Varaždina, nastojeći ih upoznati s osnovnim obilježjima flore i faune te s geološkim prilikama na varaždinskom području. ${ }^{3}$ Zajedno s nekoliko svojih kolega iste godine poveo je učenike na izlete u Varaždinske Toplice, Lepoglavu, Ivanec i Ptuj gdje su profesori učenicima neposredno na terenu ukazali na prirodopisne, geološke, povijesne i gospodarske zanimljivosti posjećenog prostora. Izvješće varaždinske Gimnazije za školsku godinu 1911./12. također navodi kako je profesor Košćec tijekom godine više puta poveo učenike na kraće zoološke i botaničke izlete u varaždinsku okolicu kako bi ih upoznao s najvažnijim biljkama u naravi s njihovim morfološkim i biološkim osebinama, te s utjecajem tla na razvoj biljnog svijeta. ${ }^{4}$ Uz već redovite kraće izlete u okolicu grada, za učenike osmog gimnazijskog razreda, u periodu od 10. do 12. svibnja 1913. godine, bio je organiziran trodnevni izlet u Kranjsku. Pod stručnim vodstvom četvorice profesora učenike se željelo upoznati s obilježjima alpskog i krškog prostora pri čemu je realiziran i posjet Postojnskoj jami. ${ }^{5}$ Iako su se prema metodama rada i svrsi ovi izleti u mnogočemu preklapali s idejama Mate Mudrinića, oni su isključivo služili nastavi i njenim ciljevima.

Početak Velikog rata bečkom je režimu otvorio mogućnost za uvođenje izvanrednog stanja. Ukidanjem ustavnog poretka društveni i politički život u državi bio

2 Siniša HORVAT: Prosvjetno-pedagoški rad profesora Franje Košćeca, Zbornik radova „Franjo Koščec i njegovo djelo 1882.-1968.", HAZU Zavod za znanstveni rad u Varaždinu, Gradski muzej Varaždin, Prva gimnazija Varaždin, Hrvatsko entomološko društvo, Zagreb - Varaždin, 2008.

3 Izvještaj kr. Velike gimnazije u Varaždinu za školsku godinu 1910.- 11., Tjelesni uzgoj, str. 110 - 111.

$4 \quad$ Izvještaj kr. Velike gimnazije u Varaždinu za školsku godinu 1911.- 12., str. 89.

5 Izvještaj kr. velike gimnazije u Varaždinu za školsku godinu 1912.- 1913., str. 78 - 80. 
je umrtvljen, a u Kraljevini Hrvatskoj, Slavoniji i Dalmaciji je posebnom Banskom naredbom, bilo onemogućeno djelovanje svih udruga i korporacija, dok je osnivanje novih bilo zabranjeno. Sasvim drugačiji stav bio je zauziman prema organizacijama koje bi mogle pomoći pri boljem i učinkovitijem funkcioniranju vojnih i državnih službi u ratnim uvjetima. Postojeću skautsku organizaciju režim je nastojao uključiti u izgradnju sustava koji bi sveukupnost napora u vođenju rata učinio što djelotvornijom. Skautske udruge i vještine njihovog članstva nastojalo se iskoristiti pri obavljanju raznih poslova poput organiziranja zbjegova, pružanja pomoći u zbrinjavanju i evakuaciji stanovništva, izviđanju te pružanju potpore pri obavljanju poljoprivrednih radova te u organizaciji vatrogasnih i sanitetskih službi. Stoga ne treba čuditi da je i inicijativom središnjih monarhijskih vlasti i Odjel za bogoštovlje i nastavu kr. zemaljske vlade u Zagrebu svojim Otpisom od 13. kolovoza 1914. godine, br. 21453, upućenim srednjim školama pod svojom ingerencijom naglasio sljedeće: „...živo se preporučuje osnivanje skautskih udruženja srednjoškolske mladeži“ ${ }^{6}{ }^{6}$ Drugim riječima, podupiralo se njihovo funkcioniranje, a tamo gdje one dotad nisu djelovale, poticalo se njihovo formiranje.

U skladu s navedenim, na poticaj dr. Vjekoslava Pachera, tadašnjeg izuzetno poduzetnog ravnatelja varaždinske kraljevske velike gimnazije, u školi je po izbijanju Prvog svjetskog rata bila osnovana neka vrsta skautske organizacije. ${ }^{7}$ Njezini primarni zadaci bili su predviđeni: pružanje pomoći pri prihvaćanju i njezi ranjenika, pružanje podrške gradskim i državnim službama te pomaganje vojnicima pri prolasku i boravku u gradu. Od šezdesetak gimnazijalaca, uglavnom polaznika viših gimnazijskih razreda, koji su se na samom početku učlanili u skautsku organizaciju bilo je oblikovano pet skautskih družbi. Uz već spomenutog profesora Košćeca, na čelo svake družbe bio je imenovan po jedan od mlađih profesora kao njezin kurator, dok je za voditelja svake pojedine družbe bio postavljen po jedan maturant. ${ }^{8}$ Tako je primjerice za kuratora prve družbe bio imenovan profesor povijesti i zemljopisa, Dragutin Marić, voditelj je bio maturant Krešimir Somogji, a sastojala se od deset članova. Kurator druge družbe bio je također profesor povijesti i zemljopisa, Adolf Wissert, voditelj Nikola Pečornik, a činila su je dvanaestorica članova. Treću družbu je predvodio maturant Vladimir Vilković, za kuratora je bio postavljen profesor Franjo Košćec, a u početku je brojila deset članova. Profesor klasičnih jezika Josip Pauković bio je imenovan kao kurator četvrte družbe, dok je za voditelja družbe postavljen Milan Lacković, a sastojala se od dvanaest članova. Kurator posljednje, pete družbe postao je vjeroučitelj Karlo Zloch, voditelj maturant Stjepan Kropek,

Izvještaj kr. velike gimnazije u Varaždinu za školsku godinu 1914.- 1915., str. 80.

Izvještaj kr. velike gimnazije u Varaždinu za školsku godinu 1914.- 1915., str. 87.

Hrvatsko pravo, br. 9 od 22. VIII. 1914., str. 6. 
dok su je činila trinaestorica članova. ${ }^{9}$ Među članovima skautskih družbi bilo je učenika koji su jedva navršili petnaest godina, ali su se među njima nalazila i imena kasnije poznatih stručnjaka i varaždinskih javnih djelatnika.

Pojedinim družbama su prema trenutnim potrebama bile dodjeljivane različite zadaće. U nastojanju da se osigura njihova podrška u funkcioniranju gradskih i državnih službi, članovi skautskih družbi su od prvoga dana počeli obavljati različite dužnosti na kolodvoru, pošti, kod kr. sudbenoga stola, kr. državnoga odvjetništva, kr. kotarskoga suda te u poslovnici varaždinske podružnice Crvenog križa. Posebno praktičnom se pokazala njihova kurirska djelatnost koju su obavljali na biciklima, pomažući liječnicima i službenicima. Isto tako su članovi gimnazijske skautske udruge bili sustavno protokolarno uključivani u javne manifestacije. Početkom rata skauti su organizirano sudjelovali u demonstracijama koje je režim inicirao protiv sila Trojnog sporazuma, posebno protiv Srbije. ${ }^{10}$ Skauti su isto tako sudjelovali u prigodnim paradama i mimohodima poput one koja je bila upriličena povodom obilježavanja rođendana kralja Franje Josipa I. ${ }^{11}$ a redovito su se priključivali ispraćajima i odavanju posljednje počasti poginulim vojnicima. ${ }^{12}$

Na varaždinskom željezničkom kolodvoru su svakoga dana od 9 sati ujutro pa do 19 sati navečer, redovito bila angažirana po šestorica članova skautske družine sa zadaćom da pomognu vojnicima pri prolasku kroz Varaždin. Njihova se zadaća sastojala u tome da prilikom zaustavljanja vlakova na peronima, vojnicima koji nastavljaju putovanje, dostavljaju vodu, cigarete i duhan koji je za tu svrhu bio prikupljan od raznih darovatelja. Isto tako su vojnicima koji su se u Varaždinu iskrcavali iz vlaka, davali dragocjene informacije koje bi im mogle pomoći pri snalaženju u gradu.

\section{POMOĆ RANJENICIMA}

Jedno od područja na kojem je skautska organizacija varaždinske Gimnazije početkom Prvog svjetskog rata ostvarila značajne, hvale vrijedne rezultate bilo je pružanje pomoći prilikom prihvata i njegovanja ranjenih vojnika zbrinjavanih u varaždinskim rezervnim vojnim bolnicama. Kako bi skauti bili osposobljeni za pomoć kod prijenosa ranjenika i pridonijeli njihovom njegovanju i bolničarskoj službi, ravnatelj Pacher je zadužio gimnazijskog učitelja higijene, doktora Aleksandra

\footnotetext{
Izvještaj kr. velike gimnazije u Varaždinu za školsku godinu 1914.- 1915., str. 88 - 89.

10 Hrvatsko pravo, br. 9 od 22. VIII. 1914., str. 3.

11 Hrvatsko pravo, br. 9 od 22. VIII. 1914., str. 4.

12 Sprovod našega prooga preminuloga ratnika, Hrvatsko pravo, br. 15/2 od 6. X. 1914., str. 2.
} 
Ernsta da članovima skautske organizacije održi bolničarski tečaj. ${ }^{13} \mathrm{U}$ okviru spomenutog tečaja, on je u periodu od 8. do 22. kolovoza 1914. godine, prvo održao teorijska, a nakon toga i praktična predavanja iz područja prve pomoći, prenoseći članovima skautskih družbi temeljna znanja o službi bolničara te o transportiranju i njezi bolesnika. Kako bi predavanja polučila što bolji praktični učinak, varaždinsko dobrovoljno vatrogasno društvo stavilo je polaznicima ovog tečaja na raspolaganje svoju opremu za prenošenje ranjenika i bolesnika. ${ }^{14}$ Ova su predavanja, uz gimnazijske skaute pohađali i neki varaždinski sveučilištarci koji su se ubuduće priključivali skautima u njihovim aktivnostima. Nakon završetka bolničarskoga tečaja skauti su bili sustavno uključivani u aktivnosti prihvaćanja i prijenosa ranjenika u bolnice te su počeli obavljati bolničarsku službu u pojedinim rezervnim vojnim bolnicama. Jedna od takvih privremenih vojnih bolnica bila je uređena i u zgradi varaždinske Gimnazije koja je bila pripremljena za zbrinjavanje približno četiri stotine osoba. ${ }^{15}$

Posebnu požrtvovnost skauti su pokazivali pomažući kod prihvata ranjenika prilikom njihovog dopremanja s bojišta. Varaždin je bio na strateški povoljnom položaju, dovoljno udaljen od crte bojišta da bude relativno siguran od borbenih aktivnosti, ali dobro prometno povezan željeznicom. U njemu je stoga bilo organizirano više rezervnih vojnih bolnica u koje su bili dopremani ranjeni vojnici najvećim dijelom s takozvanog južnog bojišta prema Srbiji. No trebalo je organizirati njihovo prihvaćanje na željezničkom kolodvoru, što je podrazumijevalo iskrcavanje iz željezničkih vagona, asistenciju pri njihovoj okrijepi na kolodvoru, ukrcavanje u prijevozna sredstva te pratnju transporta ranjenih vojnika do bolnice u čemu će se pomoć gimnazijskih skauta i varaždinskih sveučilištaraca pokazati kao vrlo dragocjena.

Prvi transport ranjenih vojnika stigao je u Varaždin 28. kolovoza 1914. Godine, ${ }^{16}$ dakle jedva mjesec dana nakon službenog početka rata. Večernjim vlakom bilo je dopremljeno ukupno četiristo sedam ranjenika koje su na kolodvoru dočekali aktivisti varaždinske podružnice Crvenog križa, vatrogasnog društva i pripadnika gimnazijske skautske organizacije. Nakon što su im aktivistice organizacije Crvenog križa osigurale osvježenje i opskrbile ih cigaretama i duhanom, ranjenici su bili pripremljeni za prijevoz u vojnu bolnicu u Topničkoj vojarni. Dok su teži ranjenici bili prebacivani ambulantnim vozilima, lakši ranjenici bili su prevezeni privatnim automobilima i zaprežnim kolima koja su na raspolaganje stavili seljaci iz varaždinske okolice. Posebno zanimljiva bila je reakcija varaždinskih građana koji su duž

13 Izvještaj kr. velike gimnazije u Varaždinu za školsku godinu 1914. - 1915., str. 87.

14 Hrvatsko pravo, br. 9 od 22. VIII. 1914., str. 6.

15 Siniša HORVAT: Povijest varaždinske Gimnazije od utemeljenja do obilježavanja 350. obljetnice njezina djelovanja, Gimnazija u Varaždinu 1636.-2006., Varaždin 2006., str. 36.

16 Hrvatsko pravo, br. 10 od 29. VIII. 1914., str. 4. 
ulica kojima su ranjenici bili prevoženi, oblikovali neprekinuti lanac ljudi, koji su šutnjom pozdravljali pristigle junake i putem ih zasipali cvijećem. ${ }^{17}$

Sljedeći ovakav transport ranjenika u Varaždin je pristigao 18. rujna 1914. godine u 11 sati prijepodne. Ovom prilikom bilo je dopremljeno stotinu dvadeset novih teško ranjenih vojnika, koji su, uz pomoć aktivista podružnice Crvenoga križa, vatrogasaca i pripadnika skautskih udruga, bili preuzeti i prevoženi u ovdašnje bolnice. ${ }^{18} \mathrm{U}$ ovakvim su prilikama brojni varaždinski kočijaši i privatnici redovito $\mathrm{u}$ organizaciji Crvenog križa stavljali na raspolaganje svoje kočije. U dirljivom pismu zahvale koje je u ime Momčadi bosanskih regimenta uputio Varaždincima, inzistirajući kod urednika Hrvatskog prava da ga objavi, kaplar Osman Asanović je o gimnazijskim skautima napisao sljedeće: „Kod prenašanja iz vagona u kola osobito se istakoše gospoda gimnazijalci, koji nijesu žalili ni truda ni muke, samo da nam olakšaju boli. Kad sam se vozio, a kiša je lijevala, opazim više žena gdje plaču, te ih pitam za razlog, odgovoriše, da plaču od ganuća, kad vide kako ti skauti rade požrtvovno. Oni prate pojedina kola u bolnicu bez kišobrana, jer kišobrane dadoše nama. Vidio sam, gdje se je iz mnogih i voda cijedila". ${ }^{19}$

Premda je njegov dolazak bio najavljen za prethodnu večer, novi transport ranjenih vojnika stigao je u Varaždin 24. rujna 1914. godine u 2 sata 25 minuta ujutro, sa zakašnjenjem većim od pet sati. ${ }^{20}$ Stoga su u očekivanju transporta još prethodne večeri na kolodvoru bile poduzete sve pripreme za brz i nesmetani prijevoz ranjenika, a detaljan opis ove operacije objavilo je varaždinsko Hrvatsko pravo. Uz brojno građanstvo, dočeku ranjenika prisustvovali su vladin povjerenik Stjepan pl. Belošević, podžupan Gaj, gradski kapetan Antun Antunović, gradski fizik Hinko Blau i posadni liječnici. Uz momčad postajnog zapovjedništva predviđenu za prijenos, u akciju su se, kao i svakom prilikom, prvi uključili sveučilištarci i gimnazijski skauti, zatim članovi podružnice Crvenog križa, vatrogasci i dio građanske čete.

Čitavom akcijom preuzimanja ranjenika vrlo uspješno je rukovodio poručnik varaždinskog postajnog zapovjedništva, Stjepan pl. Leitner. Po dolasku vlaka u akciju su stupili sveučilištarci i pripadnici treće, četvrte i pete družbe gimnazijskih skauta koje su predvodili gimnazijski ravnatelj Vjekoslav Pacher osobno te njihovi kuratori, profesori Zloh, Pauković i Koščec. Ranjenici su iz vagona prvo bili prenašani u prostorije kolodvorskih čekaonica, gdje su se za njihovo osvježavanje toplim napitcima poput kave i čaja te hranom, pobrinule aktivistice organizacije Crvenog

\footnotetext{
Isto.

18 Hrvatsko pravo, br. 13 od 19. IX. 1914., str. 3.

19 Hrvatsko pravo, br. 13/4 od 24. IX. 1914., str. 2.

20 Hrvatsko pravo, br. 13/4 od 24. IX. 1914., str. 2.
} 
križa, gospođe. Blau, Berger, Vanjek, grofica Poezay, Riedl, Gelert, Kraus, Marković te gospođice Križan i Štamberger predvođene od predsjednice podružnice gospođe Melanije pl. Belošević. ${ }^{21}$ Ovom prilikom bila su prihvaćena ukupno stotinu četiri ranjenika, većim dijelom dopremljena s balkanskog ratišta. Nakon okrijepe ranjenici su bili prebačeni na kola, kojima su potom bili prevezeni u bolnice, a za čitavu opisanu operaciju od dolaska transporta do smještanja ranjenika pod bolnički krov bilo je potrebno vrijeme od jedva jednog sata.

Budući da su prilikom njegovanja bolesnika pokazivali osobito zalaganje, pripadnici skautskih družbi bili su angažirani u pet bolnica, gdje su redovito bili na raspolaganju i liječnicima i ranjenicima. ${ }^{22}$ Za uloženi trud su im se ranjeni vojnici, između ostalog, nastojali odužiti i pismima zahvale javno objavljenim putem tiska. Tako je primjerice, razvodnik Frane Vujić u ime ranjenika Dalmatinaca i Bosanaca u Hrvatskom pravu objavio: „Mi vojnici Dalmatinci i Bosanci iz sobe br. 60. čutimo se ponukanima, da se zahvalimo svima našim dobročiniteljima. Hvala i nadobudnim skautima, koji nas dvore, svačim, štogod želimo ne mareći za daljinu puta. Hvala im jer nam pišu pisma k našim milima u rodni zavičaj“. ${ }^{23}$

Kako bi vojnicima i ranjenicima mogli što učinkovitije pomagati pri održavanju kontakata s njihovim obiteljima, pripadnici gimnazijskih skautskih družbi organizirali su i dežurstva na pošti. Po dva člana skautske organizacije od početka su redovito dežurala u varaždinskom poštanskom uredu. Dežurstvo je bilo organizirano u dvije smjene, od 8 do 12 sati ujutro te od 14 do 18 sati poslije podne, a svodilo se na pružanje pomoći kod otpremanja pisama i novca. ${ }^{24}$

Budući da je, zahvaljujući stalnom porastu broja dopremanih ranjenika, za okrepu prilikom njihovog prihvaćanja bilo potrebno sve više sredstava, dok je za njihovo zbrinjavanje i njegu te za redovito funkcioniranje rezervnih vojnih bolnica trebala sve veća količina živežnih namjernica, sredstva kojima je raspolagala organizacija Crvenog križa ubrzo su se pokazala kao nedostatna. Stoga su aktivisti varaždinske podružnice Crvenoga križa počeli sustavno obilaziti seoska naselja šire varaždinske okolice kako bi u seoskim domaćinstvima prikupljali dobrovoljne priloge u hrani i živežnim namjernicama potrebne za zbrinjavanje ranjenih vojnika. Tehničku pomoć pri obilasku terena i prenošenju prikupljenog, pritom su im pružali pripadnici skautskih družbi. Obilazeći naselja ludbreškog kotara u pratnji dvojice skauta, članice podružnice Crvenoga križa, gospođice Belčić i Vanjek su primjerice, sredinom listopada 1914. godine, naišle na izuzetnu požrtvovnost tamošnjih seljana.

\footnotetext{
21 Isto.

22 Izvještaj kr. velike gimnazije u Varaždinu za školsku godinu 1914.- 1915.

23 Hrvatsko pravo, br. 14/3 od 30. IX. 1914., str. 2.

24 Hrvatsko pravo, br. 9 od 22. VIII. 1914., str. 3.
} 
Opisujući spomenutu akciju Hrvatsko pravo je naglasilo: „Svud, kud su spomenute gospodjice došle, a bile su to većim dijelom naše skromne seljačke kolibice, primljene su po našim seljacima lijepo, ter nakon razloženja svrhe njihovog dolaska obilno nadarene raznim živežnim sredstvima za ranjenike“. ${ }^{25}$

No varaždinsko gradsko poglavarstvo i njegove zdravstvene službe na čelu sa gradskim fizikom, bili su u potpunosti svjesni činjenice da preuzimanje transporta s ranjenicima i njihovo zbrinjavanje, predstavljaju realnu opasnost za širenje zaraznih bolesti među domicilnim stanovništvom. Već početkom kolovoza 1914. godine u Varaždinu su bili zabilježeni prvi slučajevi šarlaha. Stoga je u cilju uspješnog provođenja preventivnih mjera 28. kolovoza bila sazvana sjednica Zdravstvenog odbora kojim je predsjedao gradonačelnik dr. Pero Magdić. Na prijedlog gradskog fizika dr. Hinka Blaua bile su razmatrane dvije točke dnevnog reda, mjere protiv širenja šarlaha i mjere protiv širenja kolere. ${ }^{26} \mathrm{~A}$ kad se u rujnu proširila vijest o pojavi kolere u Ugarskoj, varaždinsko gradsko poglavarstvo i njegove zdravstvene službe su, reagirajući preventivno, 4. listopada 1914. godine, građanstvu objavili oglas o mjerama koje se moraju provoditi kako bi se spriječilo širenje kolere i drugih zaraznih bolesti. ${ }^{27}$

Vlak sa četiri stotine novih, većim dijelom teških ranjenika u Varaždin je stigao u 8 sati ujutro 14. listopada 1914. godine. Prema već razrađenoj proceduri, dočekani su od strane podružnice Crvenoga križa, predstavnika vlasti, aktivista skautske organizacije i velikog broja građana. ${ }^{28} \mathrm{U}$ jutarnjim satima 6. studenoga 1914 . bio je dopremljen novi transport ranjenika. Oko tri stotine ranjenih vojnika bilo je organizirano prevezeno s kolodvora i prema već razrađenom modelu, zbrinuto u ovdašnjim bolnicama. ${ }^{29}$ No u nekim rezervnim vojnim bolnicama počeli su se pojavljivati slučajevi zaraznih bolesti. Tijekom listopada 1914. godine u bolnicu su primjerice, stigli ranjenici koji su već bili zaraženi trbušnim tifusom, dok su se početkom veljače 1915 . pojavili i slučajevi pjegavog tifusa. ${ }^{30}$ Zbog opasnosti po zdravlje civilnog stanovništva te u strahu od mogućeg širenja zaraze i izbijanja epidemija, na poziv gradskoga fizikata bila je donesena odluka da se pripadnike skautskih družbi povuče s poslova prihvaćanja i njege ranjenih vojnika. ${ }^{31}$ Premda su transporti s ranjenim

\footnotetext{
25 Iz varaždinske okolice,Hrvatsko pravo, br. 16 od 11. X. 1914., str. 3.

26 Višnja BUREK: Djelovanje poglavarstva grada Varaždina u ratnim godinama 1914. i 1915., Varaždin i sjeverozapadna Hrvatska u Velikom ratu 1914.- 1918. Zbornik radova HAZU Zavod za znanstveni rad u Varaždinu, Zagreb - Varaždin 2014., str. 294.

27 V. BUREK: isto, str. 295.

28 Hrvatsko pravo, br. 16/3 od 14.. X. 1914., str. 2.

29 Hrvatsko pravo, br. 19/5 od 6. XI. 1914., str. 2.

30 V. BUREK: isto, str 296.

31 Izvještaj kr. velike gimnazije u Varaždinu za školsku godinu 1914.- 1915., str. 88.
} 
vojnicima i nadalje pristizali u Varaždin, pripadnici gimnazijskih skautskih družbi više nisu sudjelovali u njihovom prihvatu i zbrinjavanju.

\section{ZAMIRANJE SKAUTSKE AKTIVNOSTI}

Aktivnost gimnazijskih skautskih družbi se, zbog bojazni od širenja zaraze, tijekom godine počela drastično smanjivati is vremenom je bila svedena uglavnom na njihovu asistenciju kod javnih službi, prvenstveno uz službu na kolodvoru i na pošti. U gimnazijskim Izvješćima za školsku godinu 1914./15. konstatirano je: „Dalja i prava djelatnost skautskoga udruženja nije se mogla ove školske godine da provede, jer nastale prilike nijesu dopuštale. Ravnateljstvo i učiteljski zbor ovoga zavoda nastojat će, da se buduće školske godine skautskim udruženjem u svakom pogledu potpuno ostvari ona plemenita svrha, kako su je zamišljali osnivači ovoga po mladež osobito korisnoga i patriotičkoga udruženja“. ${ }^{32}$

Potkraj školske godine zemaljske školske vlasti su, preporučajući i nadalje osnivanje učeničkih skautskih udruženja, inzistirale na nadopuni njihovih programa priređivanjem domoljubno intoniranih predavanja i sijela s deklamacijama gdje bi se njegovao kult naših junaka $i$ budilo zanimanje za vojsku, njezine uredbe $i$ za potporne akcije. ${ }^{33}$ Usprkos svemu, sljedeće 1915./16. školske godine, djelovanje skautske organizacije na varaždinskoj Gimnaziji više nije bilo obnavljano. U sljedećem su razdoblju u javnosti relativno često bile iznošene ideje o načinu i svrsi njezinog ponovnog aktiviranja koje se usprkos brojnim inicijativama, nije ostvarilo. Takva je mogućnost primjerice, bila povezana s idejom prikupljanja strateški važnih sirovina. Razmatrajući relativno loše rezultate u akciji prikupljanja metala, Hrvatsko pravo je postavilo pitanje: „Zar se nisu naši Varaždinski skauti pokazali već iz prvog početka rata vanredno požrtvovnima? Zar oni nebi mogli uz pripomoć vojničkih pomoćnih sila i predprega te kovine po kućama sabrati?“34 Slični problemi pojavili su se i kod prikupljanja vunenih otpadaka i otpadaka od gume. Varaždinsko gradsko poglavarstvo najavilo je sabirnu akciju u domaćinstvima, a ubrzo je uslijedio prijedlog da se vlasti pobrinu da se od vojske osigura besplatan podvoz, a da skauti obiđu kuće i prikupe darovane sirovine. ${ }^{35}$

Po uzoru na Upravu hrvatskih skautskih udruženja u Zagrebu, koja je tijekom ljetnih mjeseci pokušala organizirati dobrovoljnu radnu snagu za poljski rad, kao pripomoć siromašnim obiteljima, čiji su članovi na bojištu, bilo je predlagano da se i

\footnotetext{
2 Izvještaj kr. velike gimnazije u Varaždinu za školsku godinu 1914. - 1915., str. 88.

33 Visoka okružnica od 5. V. 1915. br. 11443.

34 Hrvatsko pravo, br. 24 od 12. VI. 1915., str. 1.

35 Hrvatsko pravo, br. 31 od 29. VII. 1915., str. 3.
} 
u Varaždinu učini slično. ${ }^{36}$ Tijekom ljetnog odmora na poticaj organizacije Crvenog križa, nastojalo se ranjene vojnike iznenaditi darovima za čije bi se prikupljanje po kućama i po selima varaždinske okolice, angažirali skauti. ${ }^{37}$ Uslijedile su uporne inicijative za obnavljanje rada skautskih družbi, ${ }^{38}$ uz provokativno ukazivanje kako gotovo svi gradovi imaju skautska udruženja, samo ih Varaždin nema. ${ }^{39}$ Usprkos tome u Izvješćima varaždinske gimnazije za školsku godinu 1915./16. konstatirano je: „Skautska udruženja nijesu ove škol. godine poradi osobitih ratom nastalih prilika, nikakvu djelatnost razvijala". ${ }^{40}$

\section{ZAKLJUČAK}

Premda su inicijativom mlađih profesora u varaždinskoj Gimnaziji organizirani školski izleti i stručne ekskurzije, oni pred Prvi svjetski rat nisu prerasli u izletničke ili skautske družine. Osnivanje skautskih družina na samom početku rata inicirale su monarhijske vlasti, nastojeći u ratnim uvjetima povećati efikasnost svojih javnih službi. Skautska organizacija na varaždinskoj Gimnaziji dala je značajan doprinos njihovom funkcioniranju, a posebno je pridonijela uspješnom prihvaćanju, zbrinjavanju i njezi ranjenika u rezervnim vojnim bolnicama. No upravo u navedenom području njihovog djelovanja ubrzo se pojavila i najveća poteškoća za njihov daljnji angažman. U strahu od izbijanja epidemija, usluge gimnazijskih skauta na zdravstveno-medicinskom polju su se već nakon nekoliko mjeseci intenzivnog rada, prestale koristiti. Nakon manje od godinu dana rad skautske organizacije je u potpunosti zamro, a gimnazijske školske vlasti nakon promjene ravnatelja u sljedećoj školskoj godini više nisu pokazivale zanimanje za njezino oživljavanje.

\footnotetext{
36 Hrvatsko pravo, br. 29 od 17. VII. 1915., str. 2.

37 Hrvatsko pravo, br. 32 od 7. VIII. 1915., str. 3.

38 Jedan prijedlog, Hrvatsko pravo, br. 25 od 19. VI. 1915., str. 4.

39 Hrvatsko pravo, br. 29 od 17. VII. 1915., str. 383.

40 Izvještaj kr. velike gijmnazije u Varaždinu za školsku godinu 1915.- 16., str. 83.
} 


\section{LITERATURA}

1. Herci GANZA ČALJKUŠI: Hrvatska - preteča skautizma, Povijest hrvatskog sporta br 155, 2010., str. 7 - 10.

2. Franjo Koščec i njegovo djelo 1882.-1968., HAZU Zavod za znanstveni rad u Varaždinu, Gradski muzej Varaždin Prva gimnazija Varaždin, Hrvatsko entomološko društvo, Zagreb - Varaždin 2008.

3. Višnja BUREK: Djelovanje poglavarstva grada Varaždina u ratnim godinama 1914. i 1915., Varaždin i sjeverozapadna Hrvatska u Velikom ratu 1914.- 1918., Zbornik radova HAZU Zavod za znanstveni rad u Varaždinu, Zagreb - Varaždin 2014., str. $273-299$.

4. Vladimir HUZJAN: O ranjenicima i zarobljenicima u Varaždinu 1914. i 1915. te invalidima i ratnom groblju nakon „Velikog rata“, Zbornik radova HAZU Zavod za znanstveni rad u Varaždinu, Zagreb - Varaždin 2014., str. 161 - 169.

5. Siniša HORVAT: Povijest varaždinske Gimnazije od utemeljenja do obilježavanja 350. obljetnice njezina djelovanja, Gimnazija u Varaždinu 1636.-2006., Varaždin 2006.

6. Gimnazija - SC “Gabriel Santo” Varaždin 1636-1986., Varaždin 1986.

\section{SAŽETAK}

\section{DJELOVANJE VARAŽDINSKIH GIMNAZIJSKIH SKAUTA POČETKOM PRVOG SVJETSKOG RATA}

Skautska organizacija na varaždinskoj Gimnaziji bila je utemeljena na inicijativu školskih vlasti početkom Prvog svjetskog rata, neposredno pred početak školske godine 1914./15. Njezina svrha bila je pružanje pomoći pri funkcioniranju vojnih i državnih službi u ratnim uvjetima. Pomažući gradskim i državnim službama, skauti su organizirali dežurstva i kurirsku djelatnost na biciklima. Vojnicima su osiguravali okrjepu pri prolasku kroz Varaždin i snalaženje pri boravku u gradu. Posebno značajna bila je pomoć skauta pri zbrinjavanju ranjenika. Nakon završenog bolničkog tečaja, tijekom prve ratne godine obavezno su pomagali pri prebacivanju ranjenika sa željezničkog kolodvora u bolnice, njegovanju i održavanju kontakata s obiteljima. U svrhu sprečavanja zaraza, prvo je obustavljena njihova pomoć pri zbrinjavanju ranjenika, a do kraja školske godine zamrla je njihova cjelokupna aktivnost.

Ključne riječi: Skauti; varaždinska gimnazija; Prvi svjetski rat; Varaždin. 


\section{SUMMARY}

\section{ACTIVITIES OF VARAŽDIN GRAMMAR SCHOOL SCOUTS AT THE BEGINNING OF THE FIRST WORLD WAR}

The Scout organization that operated in Gimnazija - Varaždin was founded upon the initiative of the educational authorities at the onset of World War I, at the very beginning of school year 1914/1915. Its purpose was to provide help with the operation of military and civil services during war period. By helping municipal and state services, the Scouts organized watches and courier activities on bicycles. They provided soldiers with refreshment while traversing Varaždin, as well as orientation assistance while they were stationed in the town. One of the most crucial services provided by the Scouts was helping wounded soldiers. Upon the completion of a healthcare course, during the first year of the War their basic duty was to assist with the transfer of casualties from the train station to hospitals, as well as to nurture the wounded soldiers and maintain contact with their families. In order to prevent the outbreak of diseases, at first their caretaking activity was discontinued, and by the end of the year their overall activity subsided.

Key Words: Scouts; Gimnazija - Varaždin; World War I; Varaždin.

\section{PRILOG}

\section{Popis članova skautskih družbi}

\begin{tabular}{|c|c|c|c|c|c|}
\hline Družbe & 1. družba & 2. družba & 3. družba & 4. družba & 5. družba \\
\hline Kuratori & Dragutin Marić & Adolf Wissert & Franjo Košćec & Josip Pauković. & Karlo Zloch. \\
\hline Vođe & Krešimir Somogji & Nikola Pečornik & Vlatko Vilković & Milan Lacković & Stjepan Kropek \\
\hline Članovi & $\begin{array}{l}\text { Brajdić Stanko } \\
\text { Cvek Stjepan } \\
\text { Kalabar Ferdo } \\
\text { Lvpolt Zvonimir } \\
\text { Maixner Franjo } \\
\text { Maixner Rudolf } \\
\text { Matanić Nikola } \\
\text { Milanić Arroin } \\
\text { Premuš Pavao } \\
\text { Weinberger Hinko }\end{array}$ & $\begin{array}{l}\text { Barabaš Branko } \\
\text { Belčić Mladen } \\
\text { Buzadžić Ozren } \\
\text { Domainko } \\
\text { Dragutin } \\
\text { Dumić Kriinoslav } \\
\text { Filipović Milan } \\
\text { Koos Ervin } \\
\text { Kursehner Milan } \\
\text { Palmović Ferdo } \\
\text { Plachte Milan } \\
\text { Slivar Milutin } \\
\text { Valjak Vinko }\end{array}$ & $\begin{array}{l}\text { Hercezi Ivan } \\
\text { Herrnheiser } \\
\text { Oskar } \\
\text { Jambrec Josip } \\
\text { Koos Viktor } \\
\text { Košek Dragutin } \\
\text { Levačić Josip } \\
\text { Magdić Mirko } \\
\text { Marković Dragutin } \\
\text { Švagel Josip } \\
\text { Šterk Stjepan }\end{array}$ & $\begin{array}{l}\text { Benotić Ivan } \\
\text { Deutsch } \\
\text { Aleksandar } \\
\text { Knežević Hrvoje } \\
\text { Lacb Josip } \\
\text { Lukavečki Mihovil } \\
\text { Marčec Stjepan } \\
\text { Mlinarić Viktor } \\
\text { Moses Hinko } \\
\text { Orešković Marijan } \\
\text { Sekovanić Vilim } \\
\text { Toplak Hugo } \\
\text { Vernik Vjekoslav }\end{array}$ & $\begin{array}{l}\text { Babić Ivan } \\
\text { Bratić Josip } \\
\text { Hršak Rudolf } \\
\text { Kapitarić Mirko } \\
\text { Labaš Marijan } \\
\text { Liebermann } \\
\text { Bernard Milanić } \\
\text { Eduard } \\
\text { Muller Zdenko } \\
\text { Pećnik Zvonimir } \\
\text { Rihtarić Većeslav } \\
\text { Ružička Ivan } \\
\text { Tomašić Pavao } \\
\text { Veček Eugen }\end{array}$ \\
\hline
\end{tabular}

